\title{
CONCEPTUALIZING SCHOOL EFFECTIVENESS
}

\author{
JAAP SCHEERENS* and BERT P. M. CREEMERS $\dagger$
}

*Department of Education, University of Twente, Enschede, The Netherlands $\dagger$ RION, Institute for Educational Research, University of Groningen, The Netherlands

\begin{abstract}
The theoretical status of existing school effectiveness models is analyzed by using perspectives from organizational theory and models of classroom effectiveness. This leads to the formulation of a basic framework for conceptualizing school effectiveness that includes variables at the levels of the school, the context of the school and the classroom, while background variables of pupils are also taken into account. One of the conclusions is that hypothesis construction and empirical research on cross-level relationships within this basic framework are of central importance to enhance our understanding of school effectiveness.
\end{abstract}

\section{Introduction}

School effectiveness research has its roots in quantitative sociological input-output studies and economic research on educational production functions (Coleman et al., 1966; Hanushek, 1979). The second wave of school effectiveness research emphasized 'process' rather than 'input' correlates of school output and employed in general more in-depth investigation of relatively small samples of schools (Edmonds, 1979; Brookover, Beady, \& Flood, 1979; Rutter et al., 1979). The main outcomes of this period of school effectiveness research still dominate practical thinking on school effectiveness: many school improvement projects have tried to implement these findings, with varying degrees of success (e.g., Miller, Cohen, \& Sayne, 1985).

Apart from these two research traditions, which are usually labelled as 'school effectiveness' research, a large body of research which comes under the heading of 'instructional effectiveness' should be mentioned (see Brophy \& Good, 1986, for a comprehensive review). This body of research, directed at the classroom level as opposed to that of the school, has developed independently from the school effectiveness research traditions. Recently, however, one sees a blending of approaches. In research syntheses on 'educational productivity', both input and process variables at the school and the classroom level are incorporated (Walberg, 1984; Fraser et al., 1987) and in recent effectiveness studies school and classroom level variables are combined in multilevel models of educational achievement (Mortimore, Sammons, Stall, Lewis, \& Ecob, 1988; Brandsma \& Knuver, 1988). 
The field of school effectiveness research is plagued by many methodological and technical research problems (cf. Ralph \& Fenessey, 1983; Bosker \& Scheerens, 1989). Apart from these problems, which involve seeking an appropriate way of conducting this kind of empirical research, there is very little theory on school effectiveness. Despite a growing consensus on 'what works in education', there are relatively few theoretical explanations available regarding the question 'why things work in education'. In addition to integrating school and instructional level variables in empirical research, conceptual models are needed which can serve as frameworks for hypothetical explanations of relationships between various levels of analysis of educational systems.

In this chapter it is attempted to contribute to the development of such models by means of a critique of the state of the art of conceptualizing school effectivenss (i.e., the so-called five-factor model), by examining the overall structure of a multilevel school effectiveness model and by further specifying some of the basic substantive ingredicnts of this model, most notably instructional variables and organizational and contextual conditions.

\section{Conceptual Critique of the '5-Factor' Model}

Five school characteristics are repeatedly mentioned in the literature as malleable correlates of educational achievement. These are:

- strong educational leadership

- high expectations of student achievement

- emphasis on basic skills

- a safe and orderly climate

- frequent evaluation of pupils' progress

The causal status of the '5-factor' model is correlational. This means that although the 5 factors are usually seen as 'causes' of student achievement, in a strict methodological sense no such strong statements concerning causal ordering are warranted. Further methodological criticism of the research basis on which the 5-factor model rests will not be treated here, see e.g., Ralph and Fenessey (1983). But, given the correlational status of the model, some questions about the model must be raised, also at the conceptual level.

First of all, the question of whether the factors are causes rather than effects of high achievement is particularly hard to ignore for the 'high expectation of student outcomes' factor. It is quite plausible that feedback from satisfying student results at an earlier stage leads to high expectations for the future. Perhaps the expectations-achievement correlation can best be seen as a genuine reciprocal relationship (which is hard to demonstrate using causal analysis).

Secondly, there is a hint of tautology in emphasis on basic skills (as a determinant) and exclusively measuring basic skills as the dependent variable. If one was to measure outcomes in the affective domain, instead of achievement, goal consensus on basic skills would be a less likely cause of the measured dependent variable. The basic factor here seems to be goal-measurement disparity. This variable could better have been used as a control variable or covariate, rather than as a causal factor which distinguishes effective from noneffective schools.

In the third place, the question should be raised whether the five factors are really independent factors. This question could be answered by examining the correlations between the factors. But even at face value, one might wonder whether 'frequent 
evaluation' and 'orderly climate' could not better be seen as aspects of strong instructional leadership, than as independent causes. A fourth question, which is somewhat related to the former, concerns the locus of the factors. Sometimes they are seen as all being aspects of school leadership (e.g., Sweeney, 1982), whereas in other cases they are seen as aspects of school climate. Not all the factors are exclusively defined at the school-level; progressmonitoring and evaluation should perhaps even be primarily taken as variables at the teacher or classroom level.

What remains of the 5-factor model, after considering these critical conceptual questions, is firstly a general idea of what is and what is not essential, and secondly, a feeling that more refined effectiveness models are needed. Elements like a high achievement orientation, shared by teachers and management, and both structural and cultural conditions for closely monitored learning, are the core elements of the effectiveschools model and that the methodological critique concerning the disparity (or closeness) of educational objectives and effectiveness measures points to a third condition: access to knowledge or 'opportunity to learn'.

More refined models of school-effectiveness have been developed by Glasman and Biniaminov (1981); Murphy, Weil, Hallinger, \& Mitman (1982); Clauset and Gaynor (1982); Squires, Hewitt, and Segars (1983); Schmuck (1980); Blom, Brandsma. and Stoel (1985); Ellett and Walberg (1979); and Duckworth (1983).

Usually, these models contain at least two levels at which effectiveness indicators are defined, namely the school level and the classroom level. They also take background characteristics of pupils (aptitudes, socio-economic status) into account as control variables (individual student level). Some of these models contain a third 'context' level at which effectiveness indicators are defined (Schmuck, 1980; Blom, Brandsma, and Stoel, 1985). Finally, it is worth noting that several models are nonrecursive (i.e., contain reciprocal relationships).

\section{Some Perspectives from Organizational Theory}

To a large extent empirical school effectiveness research has developed outside the field of educational administration. So, for instance, within the divisional structure of the American Educational Research Association, the Special Interest Group on effective schools belongs to the evaluation division and not to the educational administration division. In the Netherlands as well, school effectiveness researchers operate outside the professional network of researchers of educational administration. Despite some clear exceptions (e.g., Firestone \& Wilson, 1987; Hoy \& Ferguson, 1985) this institutional separation, in our opinion, has led to an underscoring of the relevance of some perspectives from organizational theory to questions of school effectiveness. Two of these perspectives are: contingency theory and alternative views on organizational effectiveness.

\section{Contingency Theory}

The research basis of the 5-factor model of school effectiveness consists largely of studies of urban primary schools with a low SES-student population conducted in the 
United States and England. The claims of the 'effective schools movement' that imply a more general applicability of the 5-factor model seem rather strong, given this relatively narrow empirical basis. The idea of a universally valid set of effectiveness indicators is at odds with a perspective in organizational theory, known as contingency theory, or 'the situational approach' (Kieser \& Kubicek, 1977; Thompson, 1967; Mintzberg, 1979). Contingency theory can be seen as a reaction against earlier organizational theories that emphasized particular ideal-type organizations, e.g., based on the ideas of scientific management or the human relations approach.

The basic idea of contingency theory is the dependency of the effectiveness of organization structures on situational or contextual conditions, such as the complexity of the environment, the nature of the core technology and factors like age and size of the organization. Organizational structures should 'fit' these contextual conditions. It should be noted that the contingency-perspective does not make the life of researchers of organizational phenomena any easier. For one thing, contingency factors are not seen as independent external causes, but as conditions that can be partly controlled by the organization. Thus, reciprocal relationships appear when one considers to empirically verify hypotheses of organizational functioning. Yet another complicating aspect of contextual determinancy is the possibility that different contingency factors "pull' the organization in different directions. Moreover, contingency hypotheses require very complicated research designs, because empirical verification of the fit of contextual and structural variables are only one step, after which it still remains to be shown whether a 'fitting arrangement' does indeed lead to effectiveness (see Kickert, 1979).

The generalizability vs. the situational dependency of the 5-factor model of schooleffectiveness is an important issue for future research in this arca. Several authors report findings that support the contingency of effectiveness indicators on factors like the distinctions between primary vs. secondary schools (Firestone $\&$ Herriott, 1982), high vs. low SES student body composition (Teddlie, Stringfield, \& Wimpelberg, 1987) and vocational vs. general secondary education (Stoel, 1986). As a further illustration of contextual determinancy of school effectiveness indicators we would like to point to a specific type of contextual dimension of schools, namely the surrounding national educational system. In Table 1.1 a general overview of school effectiveness research in the Netherlands is presented.

Table 1.1 shows that school effectiveness research in the Netherlands is still in its infancy: there are relatively few studies, all conducted during the last three to four years. The dependent variables which were used in these studies were cither achievement test data, examination results, educational attainment measures or, in two cases, affective measures like pupils' attitude towards school. The independent variables were mostly measured by means of questionnaires and interviews. Simple correlations, regression analysis and ANOVA were the most frequently used analyses. The general appearance of this overview does not offer much support for the 5-factor model of school effectiveness, although individual studies show positive results for individual factors like strong leadership, orderly climate and frequent evaluation. So, the main findings from AngloSaxon effectiveness studies are hardly replicated within the educational context of the Netherlands. This is also illustrated by Vermeulen's (1987) study, which was a close replication of an American study, conducted by Schweitzer (1984). Whereas Schweitzer found high correlations (.58 up to .79) between all five effectiveness factors and achievement, Vermeulen found only one significant correlation. It could be argued that the studies are too few and too diversified to warrant more definite conclusions. 


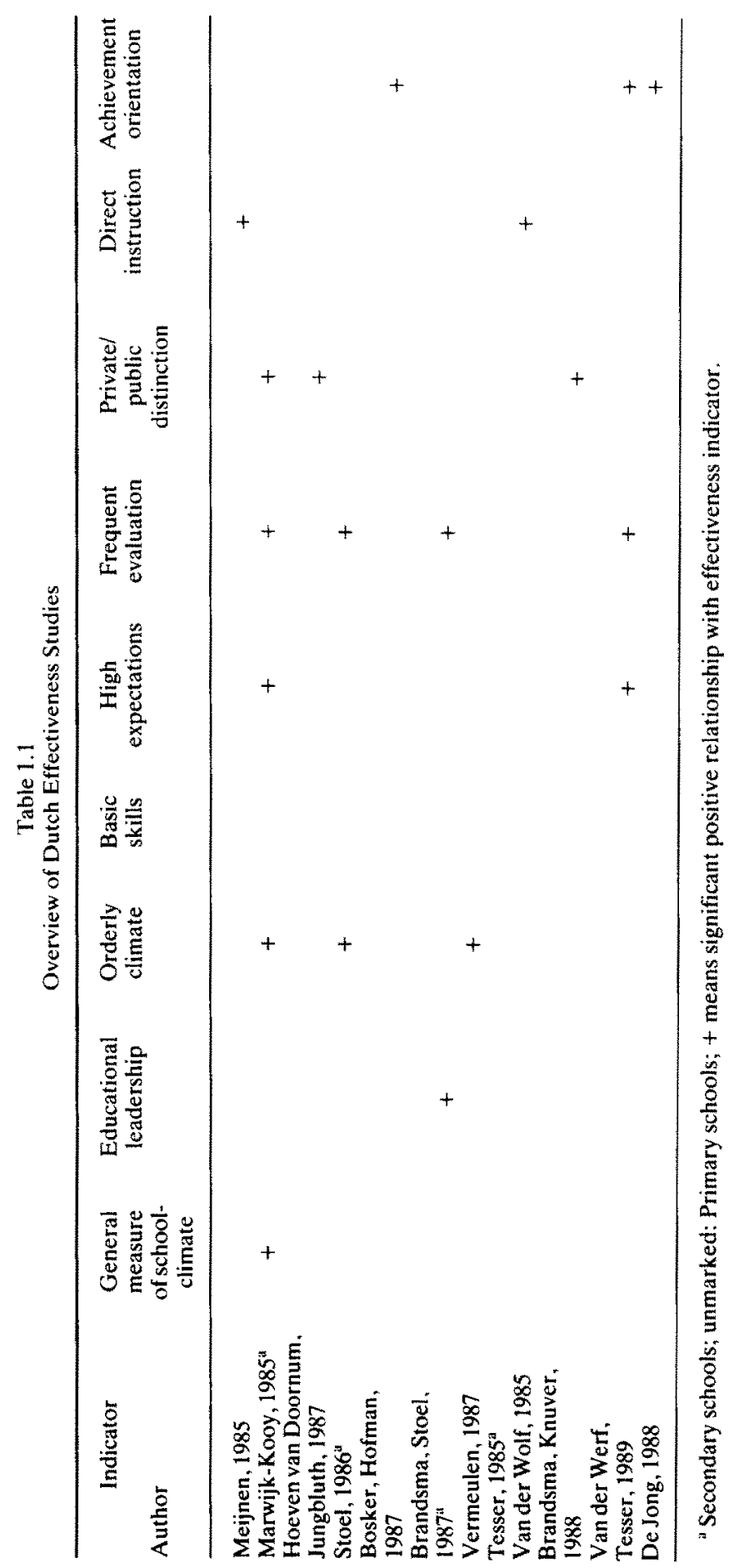


Moreover, individual studies have been criticized for lack of reliability of the measurement of the independent variables and for not using the proper techniques of analysis (e.g., Crecmers. 1987). However, such findings provoke questions about the contextual mechanisms (i.e., characteristics of the Dutch educational system) which could explain these findings.

Three tentative explanations are that : (a) Dutch schools lack a tradition of educational testing and school-based evaluation, and accordingly this variable would explain litte variance; (b) achievement orientation does not generally rank high in the teaching philosophy of Dutch schook; and (c) 'leadership', and particularly educational leadership is a phenomenon that is somewhat at odds with the predominant view of Dutch school leaders as "first among their equals" (i.e.. teachers).

\section{Alternative Views of Organizational Effectiveness}

The way effectiveness is defined in the main stream of school effectiveness reseatch conforms to the notion of organizational productivity and its theoretical background of economic rationality. The productivity view of effectiveness sees output of the organization's primary process as the criterion to judge goal attainment and emphasizes the search for organizational characteristics that maximize output. When the constraint of "least costs" is added to the maximization of output, effectiveness is transformed into the more demanding notion of efficiency.

Alternative models of organizational effectiveness use other effectiveness criteria. Table 1.2 summarizes four alternative models in addition to the productivity model.

The adaptability model emphasizes organizational survival and flexibility in responsiveness to the environment. Although requirement of vital resources (such as sufficient pupils to guarantee the continuation of a school) is a very prominent aspect of this model, the deliverance of outputs that satisfy external stake-holders (such as clients) is theoretically just as a central characteristic of this model. This last characteristic. incidentally, is a clear basis for the integration of this model and the productivity model of organizational effectiveness.

Aceording, to Niskanen (1971), however, organizations within the public sector are more concemed with accumulating resources than with the effective and efficient production of output. The model emphasizing organizational commitment is a model

Table 1.2

Models of Organizational Efrowiveness

\begin{tabular}{|c|c|c|c|}
\hline $\begin{array}{l}\text { Effectiveness } \\
\text { criteria }\end{array}$ & $\begin{array}{l}\text { Level of } \\
\text { analysis }\end{array}$ & $\begin{array}{l}\text { Focus of } \\
\text { interest }\end{array}$ & $\begin{array}{l}\text { Theoretical } \\
\text { background }\end{array}$ \\
\hline Productivity & Organization & $\begin{array}{l}\text { Output and its } \\
\text { determinants }\end{array}$ & $\begin{array}{l}\text { Economic } \\
\text { rationality }\end{array}$ \\
\hline Adaplability & Organization & Input requirement & Opensystems \\
\hline Commitment & Individual members & Motivation & Human relations \\
\hline Continuity & $\begin{array}{l}\text { Organization/ } \\
\text { individuals }\end{array}$ & Formal structure & $\begin{array}{l}\text { Theory of } \\
\text { hureaucracy }\end{array}$ \\
\hline $\begin{array}{l}\text { Responsiveness } \\
\text { to external constituents }\end{array}$ & $\begin{array}{l}\text { Subgroups within } \\
\text { organization }\end{array}$ & $\begin{array}{l}\text { Dependencies. } \\
\text { power }\end{array}$ & Political theory \\
\hline
\end{tabular}


focused on the individual members of the organization. Cohesion and morale and human resource development are important aspects of this orientation towards organizational effectiveness (Faerman \& Quinn, 1985). In contrast to the two models that were mentioned previously, this model is internally directed. Some of the five factors of school effectiveness could be seen to imply cohesiveness in (achievement oriented) values among the teaching staff. Mintzberg's (1979) characterization of the professional bureaucracy also stresses the importance of human resource development for organizations like schools. Like the organizational commitment model the continuity model is internally directed. But here formalization is seen as the major vehicle for achieving stability and control. A clear and ordered structure is seen as a vital asset of organizations. Perhaps some theorists would be willing to defend the position that the orderly climate of effective schools requires such a clear and orderly structure, the ultimate realization of which would be the classical bureaucracy.

According to Pfeffer and Salancik (1978) organizations should be seen as political battle fields, where internal subgroups draw power from relationships with important external constituencies. Organizations are actively engaged with these external constituencies and are effective to the degree in which they come to terms with the most important ones. Responsiveness to external constituencies should perhaps be seen as a specific case of the adaptability model of organizational effectiveness.

Cameron and Whetten (1983) defend the position that organizational effectiveness cannot be captured in one universal model. They say that all general theories of organizations have built in criteria for measuring effectiveness (p. 262). Some of these criteria and their underlying organizational images have been referred to above. Were one to follow Cameron and Whetten, the conclusion about the 5-factor model of organizational effectiveness would be that this model only represents a partial view of the effectiveness of schools, and that a more comprehensive treatment of school effectiveness would require independent additional criteria. Clearly, this point of view would considerably broaden the agenda of effective school research.

Although such a widening of research interests would be welcome, we do not share Cameron and Whetten's point of view that effectiveness criteria should be seen as mutually independent. The criteria mentioned in the above can be ordered according to a means-end distinction. This contention is based on the assumption that each organization has one (or several) primary output(s) to deliver (whether these are goods or services). In the case of schools, these primary outputs are the knowledge and skills pupils have acquired. Whether these vital outputs of the organization are defined as goals-to-beattained or as environmental requirements that the organizational output should meet, is relatively unimportant.

In our view, educational goals should reflect external demands on the educational system as closely as possible. In other words, the goal concept carries with it a responsiveness to external demands. So production of primary output should be taken as the ultimate criterion of organizational effectiveness. The other effectiveness criteria should be seen as supportive, or as means to this ultimate criterion. The means-to-end relationship of effectiveness criteria is depicted in Figure 1.1.

Incidentally, the arrows in Figure 1.1 should not be seen as linear relationships. It is very conceivable that overinvestment in one of the supportive criteria would be counterproductive to the ultimate criterion of maximizing output. For instance a school could 'lose itself' in doctoring the interpersonal relations among the staff to a degree where the actual work would suffer, or a school could invest so heavily in resource acquisition 


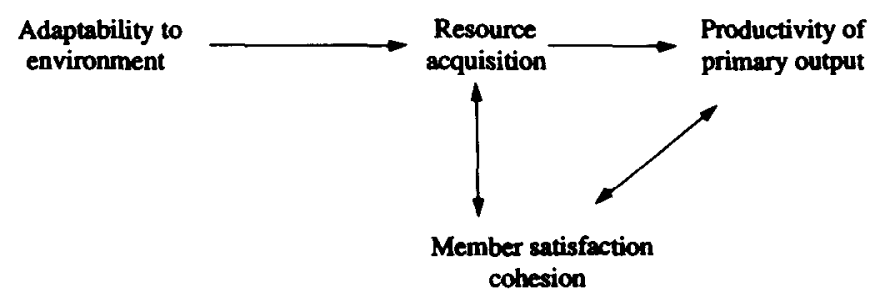

Figure 1.1

Means-to-end relationships of organizational effectiveness criteria.

that too little time and energy would be left for an achievement oriented policy. A final remark on the configuration of effectiveness criteria depicted in Figure 1.1 is that it is quite amenable to be used from the perspective of contingency theory, as described in the previous section. In a period when a school's external environment induces all kinds of new demands, it is quite understandable that a lot of energy should be spent on input characteristics like the redesign of curricula, the acquisition of new teaching materials etc. Faerman and Quinn (1985) relate changing emphasis on the alternative effectiveness criteria to an organization's life cycle.

School effectiveness research could benefit from the broader scope of conceptions of organizational effectiveness by using the 'supportive criteria' as sources of inspiration to explain the mechanism by which the factors at the 'independent' side of the productivity equation affect primary output. For instance, goal consensus and cohesion among the teaching staff could be the basis for factors like 'emphasis on basic skills' and achievement orientation. Likewise, a certain degree of formal structure (even in the professional bureaucracy) could be seen as a prerequisite for the orderly climate of effective schools.

\section{Effectiveness at the Classroom Level}

In the section on the 5-factor model of school effectiveness attention was drawn to the fact that some of the school characteristics that are thought to be associated with student achievement can also be defined at the classroom level (emphasis on basic skills, frequent monitoring of pupils' progress, an orderly atmosphere and high expectations of pupils' achievement). When one conceives of a conceptual model of school effectiveness as a causal model of student achievement, it is quite obvious that explanatory variables defined at the classroom level must be included. In fact it is to be expected that these variables explain more variance in student achievement since they are physically closer to the behavior and dispositions that are central in our measures of student achievement (empirical evidence confirming this expectation is presented by Fraser et al., 1987 and Scheerens, Nanninga, \& Pelgrum, see Chapter 8). In considering causal models of student achievement the first category of variables that must be taken into account are student background variables, such as intellectual capacity and home-environment. Although these variables explain the major part of the variance in student achievement they cannot easily be influenced by education - at least not in the short run. This means that this category of variables will mainly be used as a control factor in models of school 
effectiveness: i.e., a factor that has to be taken into account in order to facilitate interpretation of other - malleable - factors.

In the past, several models or theories have been developed which are relevant to learning in schools, such as the model of generative learning and teaching by Wittrock, Ausubel's model of meaningful verbal learning and the model of discovery learning and instruction by Bruner. The model which was most explicitly directed towards students' learning in classrooms was Caroll's (1963). This model states that the degree of learning will be a function of the amount of time the learner actually spends on the learning task relative to the total amount needed. Time actually spent on the learning task is defined as being equal to the smallest of three variables:

(a) opportunity (time allowed for learning);

(b) perseverance (the time the learner is willing to engage actively in learning);

(c) aptitude (the amount of time needed to master the task under ideal conditions, increased by whatever amount is necessary because of reduced quality of instruction and lack of ability to understand less than optimal instruction, Caroll, 1963, p. 730).

Caroll's model has given an important impetus to the development of theories and especially to the regeneration of questions and hypotheses about learning in schools. Beyond this the model is used for a diversity of developments in educational practice and research programs, such as the 'Kellerplan' for individualized instruction (Keller, 1968), 'mastery learning' (Bloom, 1974), policy research on the length of the school day and school year (Wiley \& Harnischfeger, 1974) and classroom research on time and learning (Berliner, 1979).

With respect to characteristics of instruction two variables are important, namely the 'opportunity to learn' (that is the amount of classroom time allocated to learning a subject) and the 'quality of instruction'. Besides aptitude and ability to understand the instructions, perseverance is an important variable for the explanation of students' outcomes. Perseverance is defined as the amount of time the student is willing to spend on learning, so the variable motivation should be added to a model for explanation of learning. These kinds of personal characteristics should be part of an explanatory model for learning in schools. In the meantime, factors such as perseverance are an indication that the compression of 'mastery learning' into 'academic achievement' and the operationalization of academic achievement on the different levels of education occurs in the context of the discussion concerning effective schools, whereby other outcomes of education are conceived as parts of knowledge and skills or as means to reach these goals.

An important research program based on Caroll's model and mastery learning concerns opportunity to learn. This variable is an intermediate between a pair of variables concerned with education and learning of students. In this way effects of management activities in the classroom can be measured in the extent to which the 'opportunity to learn' is enlarged, based on the hypothesis that it is ultimately 'opportunity to learn' contrasted to the amount of time the learner actually spends, which contributes to the improvement of learning results. Keller himself tones down the importance of 'time on task' and academic learning time-concepts somewhat in his recent review of research on the Caroll's model (Caroll, 1989). Methods and measures for 'time on task' are needed and in the long run the length of the school day would have adverse effects on factors such as motivation or perseverance.

As with the Keller plan, but less specifically (because there is less individualized instruction), the 'mastery learning model' seems to be effective. However, these effects 
are different for different groups of students. Recent educational research is devoted to the variable quality of instruction. Caroll's model does not deal extensively with elements involved in quality of instruction, however. With respect to quality of instruction important variables are clarity and the structure of instruction. Periodic formative testing, corrective feedback, student tutoring seem to be especially important measures in improving effectiveness. For the expansion and improvement of 'mastery learning', two conditions have to be fulfilled. First, 'mastery learning' should be part of the curriculum and of textbooks to ensure that the curriculum is organized into learning units, as opposed to book chapters, and these units should contain objective tests and corrective material. Secondly, the staff development programs are needed in order to teach teachers to teach for mastery. Specific teaching skills related to clarity of presentation, involvement of students in the learning process, provision of knowledge of results, provision of encouragement, use of test results to make instructional decisions, description of appropriate corrective instruction and monitoring of students to learning processes and outcomes are critical to the success of 'mastery learning programs' (Anderson \& Block, 1987, p. 66 and 67).

The innumerable instructional variables within 'mastery learning' and the formulation of conditions under which the model is effective, prove the importance of instructional variables, at the classroom and school level, for the explanation of educational outcomes. In this area one can make use of a long tradition of research on teaching, especially the process-product and input-throughput-output-studies. Goals in research on teaching are, just as with 'mastery learning', goals that start with the learning of students in education but add important instructional variables such as organization of groups in the classroom and more specific teaching activities directed at initiating or improving the learning process of students. An important effective instructional method is 'direct instruction' (other similar terms are 'systematic teaching'). Common characteristics are explicit, step by step instruction in which there is an emphasis upon all students practising correct responses and achieving academic success.

According to Rosenshine the following strategy by teachers seems to be most effective:

(a) give structure to the learning experience;

(b) proceed in small steps but at a rapid pace;

(c) give detailed and more redundant instructions and explanations;

(d) have a high frequency of questions and offer active practice;

(e) provide feedback and corrections, particularly in initial stages of learning new material;

(f) try for a success rate of 80 per cent or higher in the initial learning;

(g) divide seatwork assignments into smaller segments or devise ways to provide frequent monitoring;

(h) provide for continuing student practice (overlearning) so that they have a success rate of 90 to 100 per cent and become rapid, confident and firm (Rosenshine 1987, p. 258).

Some of these recommendations are the same as the variables within 'mastery learning' e.g., structuring of education, evaluation and corrective feedback. Others are more specifically aimed at 'direct instruction', such as redundancy of instruction, explanation, active participation, and sitting assignments. The supervision of sitting and homework assignments is important for the internalization of skills and knowledge and can be seen as activities for which more opportunities for practice are created and for which 'opportunity 
to learn' is enlarged. Reviews by Brophy and Good (1986), Fraser et al. (1987), and 'the International Encyclopedia of Teaching and Teacher Education' (Dunkin, 1987) emphasize that achievement is related to the quality of instruction provided by the teacher: time allocation, classroom management, opportunity to learn. Providing information, structuring, clarity and some redundancy and secrecy are important factors contributing to students' achievement. Examples of specific behavior of teachers contributing to achievement of students are: high order questions and wait time: pause between question and answer. A quiet atmosphere is seen to contribute to students' opportunity to learn or to contribute directly to higher achievement (Gump, 1967; Kounin, 1970; Doyle, 1986; Brophy \& Good, 1986 and Emmer, 1987). Teachers should also be concerned about the classroom climate. The classroom climate has an influence on students' outcomes, whereby in general a negative affect is negatively related with both cognitive and noncognitive student outcomes and a positive affect, broadly defined, does not relate consistently with achievement (Soar \& Soar, 1987).

This brief excursion into the literature on classroom effectiveness indicates a rough similarity between school-level and classroom-level correlates of student achievement, most notably with respect to factors like cvaluation and feedback, a clear achievement oriented mission, and order as a prerequisite to the quantity of instruction. In the final section this similarity will be used to sketch a model that integrates school and classroomlevel correlates of achievement.

Theory Formation within the Framework of a Contextual Multiple Criteria and Multilevel Perspective of School Effectiveness

So far, building-blocks for a conceptual map of school effectiveness have been presented. In the section in which the 5-factor model of school effectiveness was analyzed from the angle of conceptual critique it was concluded that the causal model of school achievement/attainment should be seen as a multilevel model, at least including a level of school organization and management, a teacher and/or classroom level and a level of individual student performance and background.

The conclusion from the section on contingency theory was that school context ought to be taken into account more explicitly in future school effectiveness research. Figure 1.2 depicts our analysis up to this stage.

From the review of alternative criteria of organizational effectiveness it was concluded that productivity ought to be seen as the core criterion of organizational effectiveness, whereas criteria like adaptability to the environment, cohesion and continuity could better be seen as means or supportive conditions for productivity. These supportive criteria can thus be used as explanatory principles at the various levels of Figure 1.2 and can be included in this model, instead of drawing up separate hypothetical models for each individual criterion.

It should be noted that the conceptual mapping of school effectiveness undertaken so far, does not answer the question why certain organizational characteristics correlate positively with achievement. The available models of effective learning and instruction reviewed in the previous section - offer a starting point for further understanding, however. The conceptual map, summarized in Figure 1.2 provides a framework for indicating critical relationships that are in need of further explanation, e.g., by relating the 


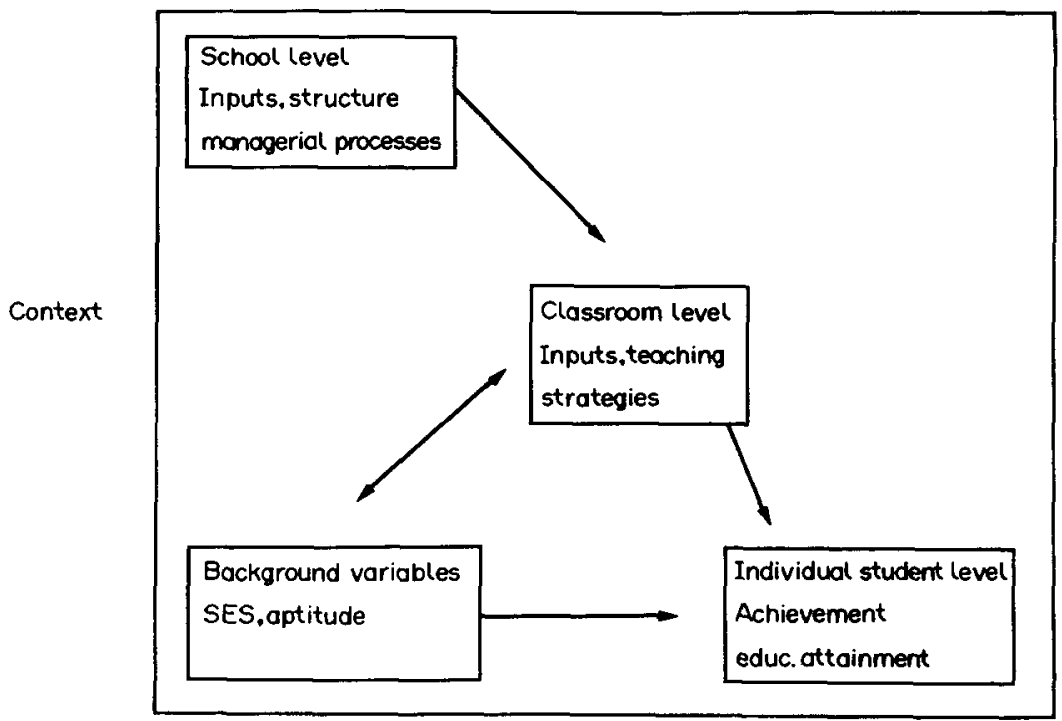

Figure 1.2

A contextual, multilevel model of school effectiveness.

already available empirical findings and new empirical hypotheses to more general principles or theories.

The critical organizational relationships in the school effectiveness model indicated in Figure 1.2 are the relationships between levels, specifically between the organizational and the classroom level and between contextual conditions and organizational characteristics. (For a similar view see Bossert, 1988). The most straightforward way of thinking about these cross-level relationships is through the idea that higher levels should provide facilitative conditions for the central processes at lower levels. This line of thinking calls for an inside-out analysis, which in this case means that our starting point for hypothesizing supportive conditions located at higher levels must be the principles of effective instruction at the classroom level. Research syntheses of instructional effectiveness and research on teaching (Walberg, 1984; Fraser et al., 1987) show that the important conditions of effective teaching include direct instruction (i.e., a conglomerate of factors such as the use of reinforcement, highly-structured learning tasks, frequent monitoring of student progress), time-on-task (including homework assignments) and opportunity to learn (i.e., closeness of achievement measurement and content covered). Fraser concludes that the amount of instruction, enhanced by using the school days more effectively or by increasing homework, especially leads to improvement in students" outcomes. In his analyses successful methods of instruction which lead to greater achievement are: mastery learning, (with emphasis on reinforcement and feedback) cooperative learning, personalized and adaptive instruction, advanced organizers, national science curricula, high teacher expectations, longer wait time and good questioning techniques.

At the next level up, one should look for managerial, structural and cultural conditions conductive to effective instruction. An important managerial condition is the provision of evaluative facilities throughout the school, regulations for frequent assessment of student 
progress, tracking systems, computerized test-service systems, absenteeism registration, procedures for school based review and teacher assessment.

This managerial principle could be summarized by referring to "the evaluative potential of the school organization" (Scheerens, 1987), which is firmly rooted in control theory, cybernetics, and rational management theory. As far as schools are concerned, an evaluation-centered, or retroactive style of management has certain advantages over a proactive, planning-centered approach (cf. Borich \& Jemelka, 1982). The concept of 'goal coordination' from control theory must be seen as an important managerial factor in establishing cohesion between school members as far as the aims and major means of effective instruction are concerned. At the cultural dimension of organizational functioning one might expect that a general orientation towards achievement, shared by school leaders and teaching personnel, would be conducive to effective teaching. Here organizational theorizing about the mission of the organization can be referred to (Mintzberg, 1979). The organizational structuring of schools in a way that is conducive to effective teaching could best be seen as a kind of optimal mixture of organic and mechanistic characteristics. On the one hand a certain degree of formalization can be seen as a necessary prerequisite to bring about continuity in relationships and an 'orderly atmosphere'. On the other hand justice should be done to the professional autonomy of teachers and enough leeway ought to be given for personal initiative.

Next, certain structural arrangements should be met to facilitate mutual adaptation and communication between teaching staff in order to establish achievement-oriented cohesion. An interesting theoretical approach to the explanation of organization-teacher relationships conducive to effectiveness is sketched by Fuller et al. (1983) in their article on the 'organizational context of individual efficacy'. They present specific hypotheses about structural determinants of individual efficacy.

At the next level, contextual conditions favorable to effective school management and organization must be explored. Here the contingency theory can be used as the general line of thinking, though this does not mean that specific contingency hypotheses are readily available. Three types of contingency hypotheses should be mentioned. First, one should expect schools to invest relatively more energy in adaptation to the environment, and, more specifically, resource acquisition, when the environment is less certain and stable. For instance, in the Netherlands, one sees at present both a decline in pupil enrolment and budget reduction. Although there is at the same time increasing pressure towards quality of school output, one should expect a trade-off in the energy schools can devote to resource acquisition and enhancement of quality of production. Probably, high pressure to accommodate to changing environmental conditions calls for different structural organizational conditions and different management-strategies in order to enhance productivity. Secondly, school-environments, for instance school districts, can be expected to differ in the degree to which schools are urged to enhance quality and productivity. When resources for schools grow scarce, one might even expect a market mechanism to start to operate, although according to our experience, schools in fact sooner compete for pupil enrolment than for output quality. Thirdly, national educational systems could be compared will respect to effectivity-stimulating contexts. Here one could differentiate between educational cultures and national policy measures that emphasize school effectiveness to a greater or lesser degree. For instance, it might be expected that educational indicator-systems, monitored at the central level, will stimulate schools to be more effective. 
Conclusion

In this chapter organizational and instructional theories were used in the analysis and interpretation of research findings on school effectiveness. Further conceptual development is necessary.

The conceptual analysis suggests that hypothesis construction and empirical research should be concentrated on cross-level relationships within a multilevel framework of school effectiveness.

In that respect the available knowledge on instructional effectiveness should be the starting point, whereupon relationships between factors at the school and classroom level should be examined from the point of view that higher level factors function as facilitative conditions to lower level factors.

Finally, attention was drawn to the importance of contextual conditions for the explanation of school effectiveness. International studies, where national contexts of school effectiveness can be compared, are quite important in this respect.

\section{References}

Anderson, L. W., \& Block, J. H. (1987). Mastery learning models. In M. J. Dunkin (Ed.), The international encyclopedia of teaching and teacher education (pp. 58-68). Oxford: Pergamon Press.

Berliner, D. C. (1979). Tempus educare. In P. L. Peterson \& J. Walberg (Eds.), Research on teaching. Berkeley: McCutchan.

Blom, M. J. T., Brandsma, H., \& Stoel, W. G. R. (1985). Effectieve scholen in hel hasisonderwijs. Groningen: RION.

Bloom, B. S. (1974). Time and learning. American Psychologist, 29, 682-688.

Borich, G. D., \& Jemelka, R. P. (1982). Programs and systems. New York: Academic Press.

Bosker, R. J., \& Hofman. W. H. A. (1987). Dimensies van schoolkwaliteit. In J. Scheerens \& W. G. R. Stoel (Eds.), Effectiviteit van onderwijsorganisaties. Lisse: Swets \& Zeitlinger.

Bosker, R. J., \& Scheerens, J. (1989). Criterion choice, effect size and stability. Three fundamental problems in school effectiveness research. In B. P. M. Creemers \& B. Reynolds (Eds.), School effectiveness and school improvement. Lisse: Swets \& Zeitlinger.

Bossert, S. T. (1988). School effects. In N. J. Boyan (Ed.), Handhook of research on educational administration. New York: Longman.

Brandsma, H. P., \& Knuver, A. W. M. (1988). Organisatorische verschillen tussen basisscholen en hun effect op leerprestaties. Tijdschrift voor Onderwijsresearch, 13, 201-212.

Brookover, W. B., Beady, C. \& Flood, P. (1979). School social systems and student achievement - schools can make a difference. New York: Praeger Publishers.

Brophy, J., \& Good, Th.L. (1986). Teacher behavior and student achievement. In M. C. Wittrock (Ed.), Handbook of research on teaching (pp. 328-375). New York: McMillan.

Cameron, K. S., \& Whetten, D. A. (1983). Organizational effectiveness. A comparison of multiple models. New York: Academic Press.

Caroll, J. B. (1963). A model of school learning. Teachers College Record, 43, 723-733.

Caroll, J. B. (1989). The Carroll Model, a 25 year retrospective and prospective view. Educational Researcher, $18,26-31$.

Clauset, K. H., \& Gaynor, A. K. (1982). A systems perspective on effective schools. Educational Leadership, $40(3), 54-59$.

Coleman, J. S. et al. (1966). Equality of educational opportunity. Washington, DC: US Government Printing Office.

Creemers, B. P. M. (1987). Bijdragen tot effectiviteit van scholen: discussie. In J. Scheerens \& W. G. R. Stoel (Eds.), Effectiviteit van onderwijsorganisaties. Lisse: Swets \& Zeitlinger.

Doyle, W. (1986). Classroom organization and management. In M. C. Wittrock (Ed.), Handbook of research on teaching (3rd ed.). New York: MacMillan.

Duckworth, K. (1983). Specifying determinants of teacher and principal work. Eugene, OR: Center of Educational Policy and Management, University of Oregon.

Dunkin. M. J. (Ed.) (1987). The international encyclopedia of teaching and teacher education. Oxford: Pergamon Press. 
Edmonds, R. R. (1979). A discussion of the literature and issues related to effective schooling. Cambridge: Center of Urban Studies, Harvard Graduate School of Education.

Ellett, C. D. \& Walberg, H. J. (1979). Principal competency, environment and outcomes. In H. J. Walberg (Ed.), Educational environment and effects (pp. 140-167). Berkely: McCutchan.

Emmer, E. T. (1987). Classroom management. In M. J. Dunkin (Ed.), The international encyclopedia of teaching and teacher education (pp. 437 446). Oxford: Pergamon Press.

Faerman, S. R., \& Quinn, R. E. (1985). Effectiveness: the perspective from organizational theory. The Review of Higher Education, 9, 83-100.

Firestone, W. A., \& Herriott, R. E. (1982). Prescriptions for effective elementary schools don't fit secondary schools. Educational Leadership, 40, $51-53$.

Firestone, W. A., \& Wilson, B. L. (1987). Management and organizational outcomes: the effects of approach and environment in schools. AERA-paper. Washington.

Fraser. B. J. et al. (1987). Syntheses of educational productivity research. International Iournal of Fdurational Research, 11 (2).

Fuller, B., Wood, K., Rappoport, T., \& Dornbush, S. M. (1983). The organizational context of individual efficacy. Review' of Educational Research, 51 (4), 509-539.

Glasman, N. S., \& Biniaminov, I. (1981). Input-output analyses of schools. Review of Educutional Research, 51, $509-539$

Gump, P. V. (1967). The classroom behavior setting, its nature and relation to student behavior. Washington, DC: Dept. of Health, Education and Welfare.

Hanushek, E. A. (1979). Conceptual and empirical issues in the estimation of educational production functions. Journal of Human Resources, 14, 351-388.

Hoeven, A. A. van der, \& Jungbluth. P. (1987). De bijdrage van schoolkenmerken aan schooleffectiviteit. In J. Scheerens, \& W. G. R. Stoel, Effectiviteit van onderwijsorganisaties. Lisse: Swets \& Zeitlinger.

Hoy, W. K., \& Ferguson, J. (1985). A theoretical framework and exploration of organizational effectiveness of schools. Educational Administration Quarterly, 21, 117-134.

Keller. F. S. (1968). Good-bye teacher . . Journal of Applied Behavior Analysis, 1. 79.89.

Kickert, W. J. M. (1979). Organization of decision-making; a systems-theoretical approach. Amsterdam: NorthHolland Publishing Company.

Kieser. A., \& Kubicek, H. (1977). Organisation. Berlin: De Gruyter.

Kounin, J. S. (1970). Discipline and group management in classrooms. New York: Holt, Rinehart \& Winston.

Marwijk-Kooij - Von Baumhauer, L. (1984). Scholen verschillen. Groningen: Wolters-Noordhoff.

Meijnen, G. W. (1984). Van zes tot twaalf. Een longitudinaal onderzoek naar de milieu-en schooleffecten van loopbaem in het lager onderwijs. Harlingen: Flevodruk.

Miller, S. K., Cohen, S. R., \& Sayre, K. A. (1985). Significant achicvement gains using the effective schools model. Educational Leadership, 43, 38-43.

Mintzberg, H. (1979). The structuring of organizations. Englewood Cliffs: Prentice Hall.

Mortimore, P., Sammons. P., Stoll, L., Lewis, D. . \& Ecob. R. (1988). School matters: the junior years. Somerset: Open Books.

Murphy, J. F., Weil, M., Hallinger, P., \& Mitman. A. (1982). Academic press: translating high expectations into school policies and classroom practices. Educational Leadership, 40 (3), 22-26.

Niskanen. W. (1971). Bureaucracy and representative government. Chicago: Aldine-Atherton

Pfeffer, J., \& Salancik, G. R. (1978). The external control of organizations. New York: Harper \& Row.

Ralph, J. H., \& Fenessey, J. (1983). Science or reform: some questions about the effective schools model. Phi De! ta Kappan, 64, Part 10, 869-695.

Rosenshine, B. (1987). Direct instruction. In M. J. Dunkin (Ed.), The international encyclopedia of teaching and teacher education (pp. 257-263). Oxford: Pergamon Press.

Rutter, M. et al. (1979). Fifteen thousand hours: secondary schools and their effects on children. Cambridge, MA: Harvard University Press.

Scheerens, J. (1987). Het evaluerend vermogen van onderwijsorganisaties. Universiteit Twente, oratie.

Schmuck, R. A. (1980). The school organization. In J. H. McMillan (Ed.), The social psychology of school learning. New York: Academic Press.

Schweitzer, J. H. (1984). Characteristics of effective schools. AERA-paper. Houston.

Soar, R. S., \& Soar, R. M. (1987). Classroom climate. In M. J. Dunkin (Ed.), The international encyclopedia of teaching and teacher education (pp. 336-342). Oxford: Pergamon Press

Squires, D. A., Hewitt, W. G., \& Segars, J. K. (1983). Effective schools and classrooms. A research based perspective. Alexandria, VA: Association for Supervision and Curriculum Development.

Stoel, W. G. R. (1986). Schoolkenmerken en het gedrag van leerlingen en docenten in het voortgezet onderwijs. Groningen: RION.

Sweeney, J. (1982). Research synthesis on effective school leadership. Educational Leadership, 39, 346-352.

Teddlie, C., Stringfield, S., \& Wimpelberg, R. (1987). Contextual differences in effective schooling in Louisiana. AERA-paper, Washington.

Thompson, J. D. (1967). Organizations in action. New York: McGraw Hill. 
Vermeulen, C. J. (1987). De effectiviteit van onderwijs bij zeventien Rotterdamse stimuleringsscholen. Pedagogische Studiën, 64, 49-58.

Walberg, H. J. (1984). Improving the productivity of American schools. Ldacational Leadership, 41, $19-27$.

Wiley, D. E., \& Harnischfeger, A. (1974). Explosion of a myth: quantity of schooling and exposure to instruction, major educational vehicles. Educational Researcher, 3, 7-12. 